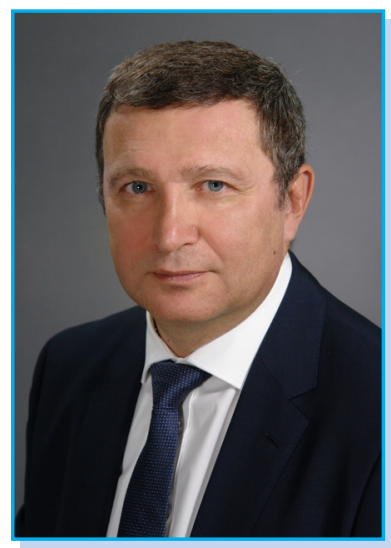

Олег Топузов - доктор педагогічних наук, професор, дійсний член (академік) НАПН України, віцепрезидент НАПН Украӥни, директор Інституту педагогіки НАПН України, м. Київ, Україна. Коло наукових інтересів: теорія і методологія організації освітнього процесу в закладах загальної середньої освіти, методика навчання географії.

$\triangle$ proftop@ukr.net

iD https://orcid.org/0000-0001-7690-1663

доктор педагогічних наук, професор, завідувач відділу дидактики Інституту педагогіки НАПН України, м. Київ, Україна.

Коло наукових інтересів: дидактика середньої та вищої школи, методологія досліджень з дидактики, реалізація компетентнісного підходу в освіті.

malykhinalex1972@gmail.com

http://orcid.org/0000-0001-6042-6298
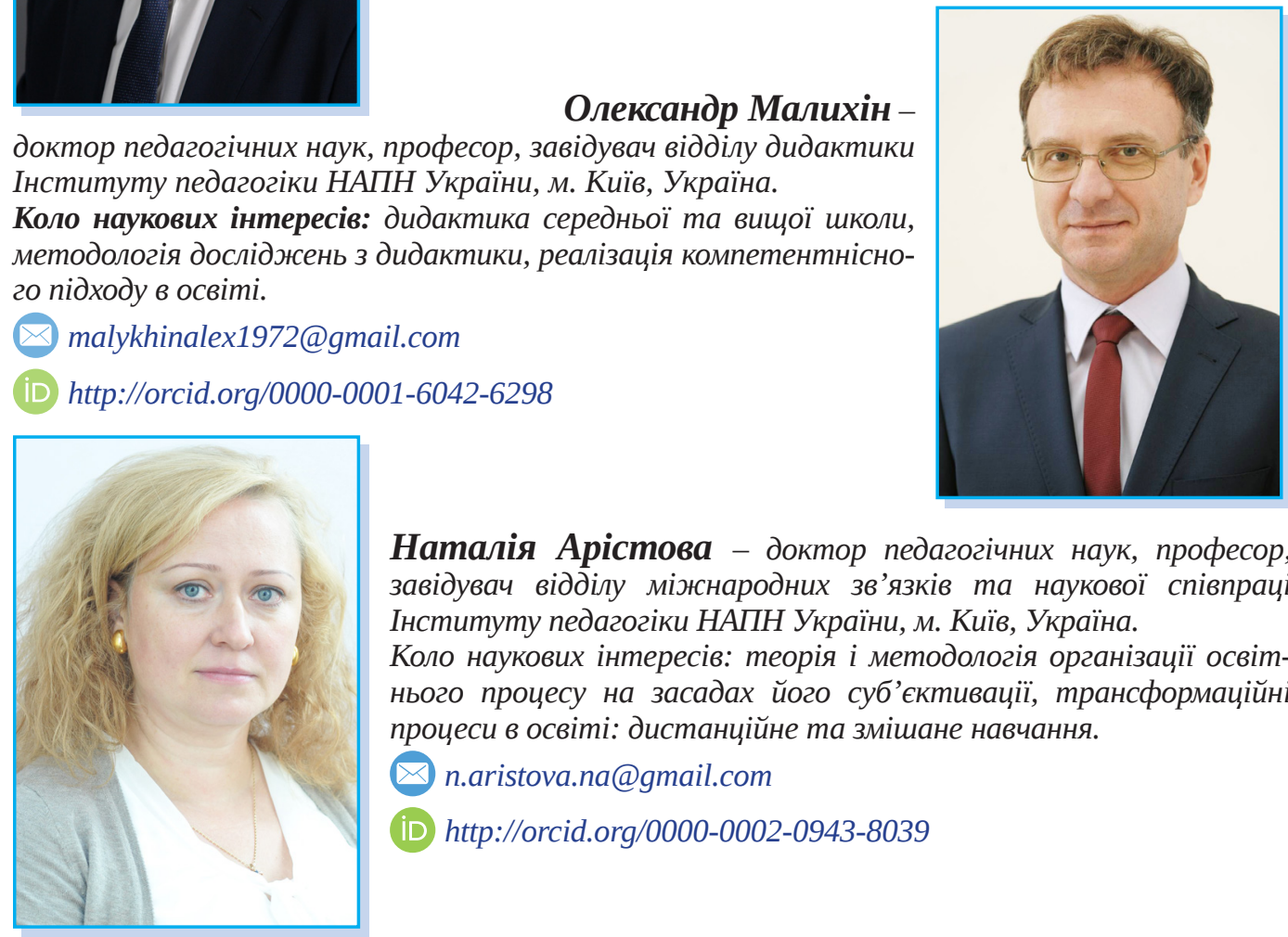

Наталія Арістова - доктор педагогічних наук, професор, завідувач відділу міжнародних зв'язків та наукової співпраці Інституту педагогіки НАПН України, м. Київ, Україна.

Коло наукових інтересів: теорія і методологія організації освітнього процесу на засадах його суб'єктивації, трансформаційні процеси в освіті: дистанційне та змішане навчання.

n.aristova.na@gmail.com

iD http://orcid.org/0000-0002-0943-8039

УДК 316.6-053.67:305

https://doi.org/10.32405/2411-1317-2021-3-5-12

\title{
ФОРМУВАННЯ ГЕНДЕРНОЇ КУЛЬТУРИ ЯК ОСНОВА РЕАЛІЗАЦІЇ ІНДИВІДУАЛЬНОГО ПОТЕНЦІАЛУ РОЗВИТКУ СТАРШОКЛАСНИКІВ
}

У статті висвітлюється формування гендерної культури старшокласників у закладах загальної середньої освіти. Проблема формування гендерної культури старшокласників на засадах розуміння гендеру й гендерної рівності зумовлена нагальною потребою в якнайшвидшому 
подоланні гендерних стереотипів і дискримінації чоловіків і жінок у сучасному українському суспільстві. На теоретичному рівні автори обгрунтовують необхідність організації освітньої діяльності старшокласників на основі усвідомлення провідних ідей гендерного підходу, що сприяє створенню необхідних умов для реалізації їхнього індивідуального потенціалу розвитку, формування навичок конструктивної міжгендерної взаємодії, і як результат, ефективно впливає на формування їхньої гендерної культури. Автори розглядають різні підходи до розуміння сутності поняття «гендер» і пропонують його власне уточнене визначення. Узагальнено принципи формування гендерної культури старшокласників, а саме: принцип доступності всіх видів і форм освітніх послуг; принцип урахування гендерних відмінностей та індивідуально-типологічних особливостей старшокласників; принцип забезпечення рівних умов для розкриття здібностей і потреб старшокласників; принцип вибору індивідуальної освітньої траєкторії.

Ключові слова: гендерна культура старшокласників; індивідуальний потенціал розвитку; навички конструктивної міжгендерної взаємодії; заклади загальної середньої освіти; принципи формування гендерної культури старшокласників.

Постановка проблеми в загальному вигляді та їі зв'язок з важливими науковими та практичними завданнями. Глобалізаційні процеси, які впливають на політичну, економічну, культурну й інформаційно-комунікаційну сфери людської діяльності, спричинили зародження нових гендерних ідеологій у сучасному світовому суспільстві й утвердження цінності гендерної рівності. Просування ідеї гендерної рівності чоловіків і жінок в Україні передбачає освоєння молодими людьми нових гендерних ролей і створення рівних умов щодо їхнього всебічного розвитку та самореалізації незалежно від статі [1]. Зважаючи на унеможливлення всебічного й гармонійного розвитку суб'єктів навчання обох статей саме через наявність у суспільстві гендерної нерівності й дискримінації, недостатнього рівня сформованості гендерної культури, державна політика України спрямована на недопущення дискримінації за ознакою статі, пропаганду гендерної рівності та поширення просвітницької діяльності в цій сфері. Відповідно до Закону України «Про забезпечення рівних прав та можливостей жінок і чоловіків» (2005р.), під гендерною рівністю розуміють «рівний правовий статус жінок і чоловіків та рівні можливості для його реалізації, що дозволяє особам обох статей брати рівну участь у всіх сферах життєдіяльності суспільства» (стаття 1) [2]. Стаття 24 Конституції України гарантує рівні конституційні права й можливості чоловіків і жінок: «Рівність прав жінки і чоловіка забезпечується: наданням жінкам рівних з чоловіками можливостей у громадсько-політичній і культурній діяльності, у здобутті освіти і професійній підготовці ...» [3]. У статті 3 (пункт 2) Закону України «Про освіту» (2017 р.) задекларовано: «В Україні створюються рівні умови доступу до освіти. Ніхто не може бути обмежений у праві на здобуття освіти. Право на освіту гарантується незалежно від віку, статі, раси, стану здоров'я, інвалідності, громадянства, національності, політичних, релігійних чи інших переконань, кольору шкіри, місця проживання, мови спілкування, походження, соціального й майнового стану, наявності судимості, а також інших обставин та ознак» [4].

Отже, проблема подолання гендерних стереотипів і формування гендерної культури серед молодого покоління громадян України є актуальною й своєчасною, оскільки незважаючи на досягнення суттєвого прогресу в різних сферах людської діяльності, у багатьох країнах світу хлопці й дівчата різного віку позбавлені рівних прав щодо отримання якісної освіти, розвитку навичок і компетентностей для навчання впродовж життя, і не мають рівних стартових можливостей щодо реалізації власного творчого потенціалу.

Аналіз останніх досліджень і публікацій з проблеми. Педагогічні й психологічні проблеми, пов’язані з гендерними реаліями в Україні, розкрито в наукових працях українських і зарубіжних учених (Т. Говорун, І. Грабовська, Т. Дороніна, О. Кікінеджі, Я. Кічук, Л. Кобелянська, І. Коган, В. Кравець, С. Кравець, Т. Марценюк, О. Марченко, С. Матюшкова, Т. Мельник, В. Москаленко, С. Стрельчук). Про необхідність подолання гендерних стереотипів ідеться також у низці законодавчих і нормативно-правових документів: Конституції України, Законі України «Про забезпечення 
рівних прав та можливостей жінок і чоловіків» (2005 р.), Законі України «Про освіту» (2017 р.), Законі України «Про повну загальну середню освіту» (2020р.). Проте, незважаючи на наявні вагомі доробки українських і зарубіжних теоретиків і практиків у цій сфері, у науково-педагогічній літературі, на жаль, недостатньо системних досліджень, присвячених проблемі формування гендерної культури старшокласників на основі реалізації фундаментальних принципів гендерного підходу.

Мета статті полягає в теоретичному обгрунтуванні необхідності формування гендерної культури старшокласників на основі провідних принципів гендерного підходу, реалізація яких в освітньому процесі закладів загальної середньої освіти сприяє розвитку навичок конструктивної міжгендерної взаємодії та розкриттю індивідуального потенціалу розвитку особистості учнів незалежно від їхньої статі. Досягнення мети передбачає застосування наступних методів: теоретичний аналіз наукових доробків українських і зарубіжних учених, котрі є суголосними проблемі дослідження; узагальнення й конкретизація теоретичних положень задля визначення поняттєво-категорійного апарату здійснюваного дослідження.

Виклад основного матеріалу. В умовах реформування загальної середньої освіти проблема формування гендерної культури старшокласників на основі реалізації провідних принципів гендерного підходу набуває все більшої популярності, оскільки зумовлена нагальною потребою в якнайшвидшому подоланні гендерних стереотипів у сучасному українському суспільстві. Факт наявності в сучасному українському суспільстві прихованих і відкритих елементів дискримінації за ознакою статі констатовано в «Концепції комунікації у сфері ґендерної рівності» (2020р.): «Присутні в суспільному житті прояви нерівності, дискримінації за ознакою статі, сексизму, насильства за ознакою статі, сексуальних домагань, ґендерні стереотипи в українському суспільстві нерідко замовчуються, що $€$ негативною тенденцією» [5]. У цьому документі також зазначено, що наявні елементи дискримінації за ознакою статі відбиваються на змісті навчальних предметів, навчально-методичної літератури, культурі взаємовідносин та стилі викладання. Ураховуючи досвід минулого В. Кравець наголошує на тому, що «... вітчизняна школа ніколи не була «безстатевою», як часто говорили. Навпаки, школа через навчально-виховний процес і педагогічну взаємодію активно реалізувала статево рольову парадигму ґендерної соціалізації учнів. Саме школі, на думку багатьох феміністських дослідниць, належить заслуга проведення ідей про природну рольову обмеженість жінок, формування комплексів професійної неповноцінності і соціальної деривації дівчат» [6, с. 113].

Провадження політики повноцінного гендерного виховання задля досягнення фактичної рівності можливостей представників обох статей стало можливим завдяки переходу до гендерної педагогічної парадигми. Системі освіти загалом і системі загальної середньої освіти зокрема відводиться важлива роль щодо забезпечення позитивних зрушень у розвитку гендерної свідомості молодого покоління громадян України шляхом набуття ними в освітньому процесі не лише грунтовних гендерних знань, умінь і навичок, а й формування гендерної культури та розширення їхнього гендерного світогляду.

Гендерний підхід $є$ «виміром суспільних явищ крізь призму сукупності світоглядних положень, які виходять з ідеї про те, що важливі не самі по собі біологічні та фізичні відмінності між чоловіками та жінками, а культурна і соціальна значущість, яка надається суспільством цим відмінностям у напрямі досягнення гендерної рівності» [7, с. 129].

В. Кравець, розглядаючи гендерний підхід як підхід, який «орієнтований на формування і створення рівних, незалежних від статевої ознаки можливостей самореалізації людини в різних сферах життєдіяльності, у виконанні статеворольових функцій чоловіка і жінки, подружніх партнерів, батька і матері, сексуальних партнерів» [8, с. 113-114], зазначає, що реалізація його провідних принципів в освітньому процесі надає суб’єктам навчання можливість здобути більшу свободу вибору й самореалізації, навчити їх бути достатньо гнучкими й уміти використовувати різні можливості поведінки.

У документі «Сприяння гендерній рівності» [9], розробленому ЮНІСЕФ, зазначено, що різні потреби й можливості, які складають основу біологічних відмінностей між чоловіками й жінками, не мають призводити до соціальної нерівності або порушення прав представників обох 
статей. Гендерна нерівність є наслідком наявності в суспільстві гендерних стереотипів і нерівних умов для розкриття чоловіками та жінками творчого потенціалу. Гендер і гендерна ідентичність лише визначають, якими мають бути чоловіки й жінки, розмежовують їхні права й обов'язки тощо. Зважаючи на те, що під гендером здебільшого розглядають соціальні ролі, які виконують чоловіки й жінки, хлопці й дівчата у певному суспільстві в конкретний час та в конкретному місці, гендерна нерівність виявляється у порушені прав людини на підставі її приналежності до певної статі. Щодо гендерної ідентичності, варто зазначити, що цей феномен виявляється в тому, яким чином чоловіки й жінки сприймають і поводять себе в сучасному суспільстві. У різних спільнотах і культурах гендерна ідентичність не $є$ чимось незмінним, оскільки може варіюватися відповідно до соціального контексту. Це здебільшого виявляється у поведінці чоловіків і жінок, хлопців і дівчат, коли вони знаходяться серед представників своєї або протилежної статі.

Аналіз наявних підходів до трактування поняттєво-категорійного апарату гендерної педагогіки надає підстави стверджувати, що гендер відображає біологічні, соціальні, культурні та історичні особливості людської істоти [10].

Так, Т. Марценюк розуміє гендер як «комплекс культурних і соціальних характеристик, що охоплює всі сфери діяльності людини» $[11$, с. 7]. На глибоке переконання вченої, набуття гендеру не відбувається автоматично, це здійснюється поступово під час взаємодії соціальних суб’єктів. А ролі, які виконують чоловіки й жінки в суспільстві, залежать здебільшого «від історичного і соціально-культурного контексту» [12, с. 7].

Актуальною $є$ думка С. Матюшкової щодо сутності гендеру. Дослідниця вважає, що гендер $€$ складним соціокультурним конструктом формування суспільством відмінностей між поведінкою й ролями, які виконують чоловіки й жінки [13, с. 19].

Власне бачення сутності поняття «гендер» пропонує I. Коган. Відповідно до міркувань науковця, гендер є «одним із системоутворювальних елементів культури: завдяки йому культура отримує цілісність, у культурних процесах беруть участь не лише символічні об'єкти (смисли, значення, вірування тощо), а й реальні люди та матеріальні (у тому числі природні) предмети» [14, с. 278], його слід розглядати як певний соціокультурний комплекс норм, правил, ідеалів, цінностей тощо.

Отже, гендер розглядаємо як складне утворення, що впливає на усвідомлення людиною своєї ролі й поведінки відповідно до соціокультурних норм і правил певної спільноти або культури, які регулюють конструктивну взаємодію між ії̈ представниками.

Сутність гендерного підходу вбачають в урахуванні різних потреб і ситуацій, у яких опиняються жінки й чоловіки через свої соціальні ролі. Головна мета упровадження його провідних принципів в освітній процес закладів загальної середньої освіти полягає, по-перше, у подоланні гендерних стереотипів і гендерної нерівності щодо наявності здібностей до вивчення певного шкільного предмету або, навпаки, їх відсутності через стать суб'єкта навчання; по-друге, у створенні сприятливих умов щодо розкриття суб' єктами навчання індивідуального потенціалу розвитку, самореалізації та забезпеченні свободи вибору незалежно від статі; по-третє, в організації спільної діяльності суб’єктів навчання обох статей, спрямованої на формування ефективної міжгендерної взаємодії.

Організація освітньої діяльності старшокласників на основі врахування принципів гендерного підходу уможливлює ефективне формування їхньої гендерної культури. У психолого-педагогічній літературі немає єдиного погляду щодо трактування зазначеного педагогічного явища. Так, наприклад, значний внесок у розуміння сутності поняття «гендерна культура» зробила С. Матюшкова. У науковій праці «Педагогічні умови формування гендерної культури учнів старших класів» дослідниця наводить два визначення поняття «гендерна культура». Учена зазначає, що гендерну культуру, по-перше, слід розуміти як культуру взаємовідносин між чоловіками й жінками, яка побудована на основі гендерних цінностей, а по-друге, як стосунки між представниками обох статей, які існують у певному суспільстві в конкретний історичний період. Дослідниця слушно додає, що гендерна культура також є невід’ємною «складовою загальної культури й сукупного показника гендерного досвіду, знань, почуттів, зразків поведінки й функціонування гендерних суб’єктів» [15, с. 31]. Зміст гендерної культури, на думку вченої, містить уявлення про маскулін- 
ність і фемінність; уявлення про соціальні ролі чоловіків і жінок у сучасному суспільстві; гендерні цінності та гендерну самосвідомість; стратегії та форми гендерної поведінки. Гендерна культура виконує певні функції, серед яких учена виокремлює комунікативну, сигніфікативну, нормативну, соціалізаційну й інформативну. В основу формування гендерної культури старшокласників мають покладатися загальні та специфічні принципи. Так, серед загальних принципів учена виокремлює наступні: системності; гуманізму; єдності дій і вимог; зв’язку з життям і соціокультурним середовищем; урахування вікових й індивідуальних особливостей; вибору, творчості й успіху. До специфічних принципів дослідниця відносить: (подання) урахування різних поглядів на гендерні проблеми; виклад навчального матеріалу, вільного від гендерних стереотипів; урахування національних особливостей і гуманізація змісту гендерного виховання.

В. Москаленко переконана, що гендерна культура є «організованою соціальними уявленнями про «чоловіче» і «жіноче» системою форм і способів людської життєдіяльності, що виконує функцію детермінанти процесу статеворольової соціалізації індивідів у кожному суспільстві» [16, с. 22]. Як складна система, гендерна культура містить певні складові, що відображають різні сторони сучасного суспільства. Серед важливих структурних компонентів гендерної культури вчена виокремлює: гендерні ролі; гендерні стереотипи; гендерний контроль; гендерну ідеологію та гендерну політику, яка провадиться в державі.

Отже, під гендерною культурою старшокласників розуміємо сукупність засвоєних ними стратегій і форм гендерної поведінки в суспільстві, яка виявляється у взаємовідносинах із представниками своєї або іншої статі.

О. Марченко наголошує, що формування гендерної культури суб’єктів навчання під час їхнього фізичного виховання має спиратися на такі принципи: цілісності різнобічного розвитку особистості; гуманізації та демократизації; диференціації й індивідуалізації; обліку психофізіологічних особливостей, інтересів і статево-рольових переваг [17, с. 340].

Ефективному формуванню гендерної культури старшокласників у закладах загальної середньої освіти сприяє реалізація сукупності певних принципів навчання [18]. До цієї сукупності відносимо принципи: доступності всіх видів і форм освітніх послуг; урахування гендерних відмінностей та індивідуально-типологічних особливостей старшокласників; забезпечення рівних умов для розкриття здібностей і потреб старшокласників; вибору індивідуальної освітньої траєкторії. Принцип доступності всіх видів і форм освітніх послуг уможливлює реалізацію права старшокласників «на освіту впродовж життя шляхом формальної, неформальної та інформальної освіти» [19]. Більш того, його дотримання в освітньому процесі закладу загальної середньої освіти надає старшокласникам можливість здобувати освіту в різних формах, які включають «інституційну (очну (денну, вечірню), заочну, дистанційну, мережеву); індивідуальну (екстернатну, сімейну (домашню), педагогічний патронаж, на робочому місці (на виробництві); дуальну» [20]. Принцип гендерних відмінностей не лише забезпечує ефективність впливу на формування гендерної культури старшокласників і особисту творчу самореалізацію незалежно від їхньої статі, а й оволодіння ними всією сукупністю ключових компетентностей для навчання упродовж життя. Це відбувається завдяки тому, що організація освітньої діяльності на основі дотримання зазначеного принципу сприяє усвідомленню старшокласниками рівних прав і можливостей щодо виконання соціальних ролей, незважаючи на наявні гендерні стереотипи, котрі досі превалюють в українському суспільстві на рівні буденної свідомості. Реалізація принципу забезпечення рівних умов для розкриття здібностей і потреб суб’єктів навчання надає вчителю змогу зосередити більше уваги на пізнавальних інтересах, нахилах і здібностях старшокласників незалежно від їхньої статевої приналежності, розвитку навичок міжгендерної взаємодії, що в кінцевому результаті призводить до їхньої успішної соціалізації в сучасному українському суспільстві. Допомога вчителя у виборі індивідуальної траєкторії навчання, котру здебільшого розглядають як «персональний шлях реалізації особистісного потенціалу здобувача освіти, що формується за урахування його здібностей, інтересів, потреб, мотивації, можливостей і досвіду, грунтується на виборі здобувачем освіти видів, форм і темпу здобуття освіти, суб’єктів освітньої діяльності та запропонованих ними освітніх 
програм, навчальних дисциплін і рівня їхньої складності, методів і засобів навчання» [21], надає старшокласникам змогу оволодіти грунтовними теоретичними знаннями щодо забезпечення рівних прав і можливостей осіб обох статей, гендерних цінностей, гендерних моделей поведінки, а також практичними вміннями та навичками аналізу й протистояння наявним ситуаціям гендерної нерівності. У контексті формування гендерної культури старшокласників слідування принципу урахування індивідуально-типологічних особливостей старшокласників сприяє розширенню їхнього життєвого простору, усвідомленню важливості всебічного та гармонійного розвитку особистості незалежно від статі, виробленню загальних поглядів і ціннісних суджень на певні явища та ситуації, а найголовніше, подоланню негативних гендерних стереотипів, котрі часто заважають реалізації власних мрій й розкриттю творчого потенціалу особистості в різних сферах людської життєдіяльності через віру в стереотипні думки.

Висновки та перспективи подалыших досліджень. Отже, організація освітньої діяльності на основі реалізації провідних принципів гендерного підходу уможливлює створення психологопедагогічних та суто організаційно-дидактичних умов для реалізації індивідуального потенціалу розвитку старшокласників обох статей, сприяє формуванню навичок конструктивної міжгендерної взаємодії, ефективно впливає на результативність формування їхньої гендерної культури.

\section{Використані джерела}

[1] Гендерні медійні практики, навчальний посібник із гендерної рівності та недискримінації для студентів вищих навчальних закладів. Київ, 2014. [Електронний ресурс]. Доступно: https://www.osce.org/files/f/ documents/c/3/284966.pdf. Дата звернення: Січень 18, 2021.

[2] Верховна Рада України. (2005, Вер. 8). Закон № 2866-IV, “Про забезпечення рівних прав та можливостей жінок і чоловіків”. [Електронний ресурс]. Доступно: https://zakon.rada.gov.ua/laws/show/2866-15\#Text.

[3] Верховна Рада України. (1996, Черв. 28). Закон України № 254к/96-ВР, “Конституція України”. [Електронний ресурс]. Доступно: https://zakon.rada.gov.ua/laws/show/254\%D0\%BA/96-\%D0\%B2\%D1\%80\#Text.

[4] Верховна Рада України. (2017, Вер. 5). Закон України № 2145-VIII, “Про освіту”. [Електронний ресурс]. Доступно: https://zakon.rada.gov.ua/laws/show/2145-19\#Text.

[5] Кабінет Міністрів України. (2020, Вер. 16) Розпорядження № 1128-р, “Концепція комунікації у сфері гендерної рівності”. [Електронний ресурс]. Доступно: https://zakon.rada.gov.ua/laws/show/1128-2020\%D1\%80\#Text.

[6] В. Кравець, «ендер у педагогічній парадигмі вузівської системи: виклики та відповіді», Українознавчий альманах, вип. 4, с. 113-117, 2010. [Електронний ресурс]. Доступно: http://nbuv.gov.ua/UJRN/ Ukralm_2010_4_26. Дата звернення: Квітень 20, 2021.

[7] Енциклопедія освіти, Київ, Україна: Юрінком Інтер, 2008.

[8] В. Кравець, «ендер у педагогічній парадигмі вузівської системи: виклики та відповіді», Українознавчий альманах, вип. 4, с. 113-117, 2010. [Електронний ресурс]. Доступно: http://nbuv.gov.ua/UJRN/ Ukralm_2010_4_26. Дата звернення: Квітень 20, 2021.

[9] Promoting Gender Equality: An Equity-Focused Approach to Programming: Operational Guidance Overview, 2011. [Online]. Available: https://www.unicef.org/gender/files/Overarching_Layout_Web.pdf. Accessed: February 26, 2021.

[10] Енциклопедія освіти, Київ, Україна: Юрінком Інтер, 2008.

[11] Т. Марценюк, Інтеграція гендерної складової в аналітичні матеріали, Київ, Україна: МФ «Відродження», 2019.

[12] Т. Марценюк, Інтеграція гендерної складової в аналітичні матеріали, Київ, Україна: МФ «Відродження», 2019.

[13] С.Д. Матюшкова, Педагогические условия формирования гендерной культуры учашихся старших классов, монография. Витебск, Республика Беларусь: ВГУ имени П. М. Машерова, 2012.

[14] И. Л. Коган, Гендерная культурология: культура пола и «пол» культуры, Минск, Республика Беларусь: Ковчег, 2003.

[15] С.Д. Матюшкова, Педагогические условия формирования гендерной культуры учашихся старших классов, монография. Витебск, Республика Беларусь: ВГУ имени П. М. Машерова, 2012. 
[16] В. Москаленко, “Нормативно-регулятивна сутність ґендерної культури суспільства”, на Міжн. наук.-практ. конф. Гендерна освіта - ресурс розвитку паритетної демократії, Тернопіль, 2011, с. 22-25. [Електронний ресурс]. Доступно: https://gender.org.ua/images/lib/tezy_ternopil_2011.pdf. Дата звернення: Березень 24, 2021.

[17] О.Ю.Марченко, Теоретико-методологічні основи гендерного підходу до формування аксіологічної значущості фізичної культури у школярів: дис. ... д-ра пед. наук, Національний університет фізичного виховання і спорту України, Київ, Україна, 2019. [Електронний ресурс]. Доступно: https://uni-sport.edu. ua/sites/default/files/vseDocumenti/diss_marchenko_o.yu.pdf. Дата звернення: Квітень 15, 2021.

[18] О.В. Малихін, Н.О. Арістова, “Формування гендерної культури старшокласників: реалізація провідних ідей гендерного підходу”, на Міжн. наук.-практ. конф. Стан освітнього процесу в умовах викликів сьогодення, Дніпро: Міжнародний гуманітарний дослідницький центр, 2021, с. 97-100.

[19] Верховна Рада України. (2017, Вер. 5). Закон № 2145-VIII, “Про освіту”. [Електронний ресурс]. Доступно: https://zakon.rada.gov.ua/laws/show/2145-19\#Text.

[20] Верховна Рада України. (2017, Вер. 5). Закон № 2145-VIII, “Про освіту”. [Електронний ресурс]. Доступно: https://zakon.rada.gov.ua/laws/show/2145-19\#Text.

[21] Верховна Рада України. (2017, Вер. 5). Закон № 2145-VIII, “Про освіту”. [Електронний ресурс]. Доступно: https://zakon.rada.gov.ua/laws/show/2145-19\#Text.

\section{References}

[1] Genderni mediini praktyky, navchalnyi posibnyk iz gendernoi rivnosti ta nedyskryminatsii dlia studentiv vyshchykh navchalnykh zakladiv. Kyiv, 2014. [Elektronnyi resurs]. Dostupno: https://www.osce.org/files/f/ documents/c/3/284966.pdf. Data zvernennia: Sichen 18, 2021. (in Ukrainian)

[2] Verkhovna Rada Ukrainy. (2005, Ver. 8). Zakon № 2866-IV, “Pro zabezpechennia rivnykh prav ta mozhlyvostei zhinok i cholovikiv”. [Elektronnyi resurs]. Dostupno: https://zakon.rada.gov.ua/laws/show/2866-15\#Text. (in Ukrainian)

[3] Verkhovna Rada Ukrainy. (1996, Cherv. 28). Zakon Ukrainy № 254k/96-VR, “Konstytutsiia Ukrainy”. [Elektronnyi resurs]. Dostupno: https://zakon.rada.gov.ua/laws/show/254\%D0\%BA/96-\%D0\%B2\%D1\%80\#Text. (in Ukrainian)

[4] Verkhovna Rada Ukrainy. (2017, Ver. 5). Zakon Ukrainy № 2145-VIII, “Pro osvitu”. [Elektronnyi resurs]. Dostupno: https://zakon.rada.gov.ua/laws/show/2145-19\#Text. (in Ukrainian)

[5] Kabinet Ministriv Ukrainy. (2020, Ver. 16) Rozporiadzhennia № 1128-r, “Kontseptsiia komunikatsii u sferi hendernoi rivnosti”. [Elektronnyi resurs]. Dostupno: https://zakon.rada.gov.ua/laws/show/1128-2020\%D1\%80\#Text. (in Ukrainian)

[6] V. Kravets, «Gender u pedahohichnii paradyhmi vuzivskoi systemy: vyklyky ta vidpovidi», Ukrainoznavchyi almanakh, vyp. 4, s. 113-117, 2010. [Elektronnyi resurs]. Dostupno: http://nbuv.gov.ua/UJRN/ Ukralm_2010_4_26. Data zvernennia: Kviten 20, 2021. (in Ukrainian)

[7] Entsyklopediia osvity, Kyiv, Ukraina: Yurinkom Inter, 2008. (in Ukrainian)

[8] V. Kravets, «Gender u pedahohichnii paradyhmi vuzivskoi systemy: vyklyky ta vidpovidi», Ukrainoznavchyi almanakh, vyp. 4, s. 113-117, 2010. [Elektronnyi resurs]. Dostupno: http://nbuv.gov.ua/UJRN/ Ukralm_2010_4_26. Data zvernennia: Kviten 20, 2021. (in Ukrainian)

[9] Promoting Gender Equality: An Equity-Focused Approach to Programming: Operational Guidance Overview, 2011. [Online]. Available: https://www.unicef.org/gender/files/Overarching_Layout_Web.pdf. Accessed: February 26, 2021.

[10] Entsyklopediia osvity, Kyiv, Ukraina: Yurinkom Inter, 2008. (in Ukrainian)

[11] T. Martseniuk, Intehratsiia hendernoi skladovoi v analitychni materialy, Kyiv, Ukraina: MF «Vidrodzhennia», 2019. (in Ukrainian)

[12] T. Martseniuk, Intehratsiia hendernoi skladovoi v analitychni materialy, Kyiv, Ukraina: MF «Vidrodzhennia», 2019. (in Ukrainian)

[13] S.D. Matiushkova, Pedahohycheskye uslovyia formyrovanyia hendernoi kultury uchashykhsia starshykh klassov, monohrafyia. Vytebsk, Respublyka Belarus: VHU ymeny P.M. Masherova, 2012. (in Russian)

[14] Y.L. Kohan, Hendernaia kulturolohyia: kultura pola y «pol» kultury, Mynsk, Respublyka Belarus: Kovcheh, 2003. (in Russian) 
[15] S.D. Matiushkova, Pedahohycheskye uslovyia formyrovanyia hendernoi kultury uchashykhsia starshykh klassov, monohrafyia. Vytebsk, Respublyka Belarus: VHU ymeny P. M. Masherova, 2012. (in Russian)

[16] V. Moskalenko, "Normatyvno-rehuliatyvna sutnist gendernoi kultury suspilstva”, na Mizhn. nauk.-prakt. konf. Henderna osvita - resurs rozvytku parytetnoi demokratii, Ternopil, 2011, s. 22-25. [Elektronnyi resurs]. Dostupno: https://gender.org.ua/images/lib/tezy_ternopil_2011.pdf. Data zvernennia: Berezen 24, 2021. (in Ukrainian)

[17] O. Yu. Marchenko, Teoretyko-metodolohichni osnovy hendernoho pidkhodu do formuvannia aksiolohichnoi znachushchosti fizychnoi kultury u shkoliariv: dys. ... d-ra ped. nauk, Natsionalnyi universytet fizychnoho vykhovannia i sportu Ukrainy, Kyiv, Ukraina, 2019. [Elektronnyi resurs]. Dostupno: https://uni-sport.edu.ua/ sites/default/files/vseDocumenti/diss_marchenko_o.yu.pdf. Data zvernennia: Kviten 15, 2021. (in Ukrainian)

[18] O.V. Malykhin, N.O. Aristova, "Formuvannia gendernoi kultury starshoklasnykiv: realizatsiia providnykh idei gendernoho pidkhodu”, na Mizhn. nauk.-prakt. konf. Stan osvitnoho protsesu v umovakh vyklykiv sohodennia, Dnipro: Mizhnarodnyi humanitarnyi doslidnytskyi tsentr, 2021, s. 97-100. (in Ukrainian)

[19] Verkhovna Rada Ukrainy. (2017, Ver. 5). Zakon № 2145-VIII, “Pro osvitu”. [Elektronnyi resurs]. Dostupno: https://zakon.rada.gov.ua/laws/show/2145-19\#Text. (in Ukrainian)

[20] Verkhovna Rada Ukrainy. (2017, Ver. 5). Zakon № 2145-VIII, “Pro osvitu”. [Elektronnyi resurs]. Dostupno: https://zakon.rada.gov.ua/laws/show/2145-19\#Text. (in Ukrainian)

[21] Verkhovna Rada Ukrainy. (2017, Ver. 5). Zakon № 2145-VIII, “Pro osvitu”. [Elektronnyi resurs]. Dostupno: https://zakon.rada.gov.ua/laws/show/2145-19\#Text. (in Ukrainian)

Oleh Topuzov, D. Sc. (Pedagogy), Professor, Full Member of the NAES of Ukraine, Director of the Institute of Pedagogy of the NAES of Ukraine, Kyiv, Ukraine.

Oleksandr Malykhin, D. Sc. (Pedagogy), Professor, Head of the Didactics Department of the Institute of Pedagogy of the NAES of Ukraine, Kyiv, Ukraine.

Nataliia Aristova, D. Sc. (Pedagogy), Professor, Head of the Department of International Relations and Research Cooperation of the Institute of Pedagogy of the NAES of Ukraine, Kyiv, Ukraine.

\section{GENDER CULTURE FORMATION AS THE BASIS FOR REALIZING INDIVIDUAL POTENTIAL OF DEVELOPMENT OF HIGH SCHOOL STUDENTS}

The article highlights the questions concerning formation of high school students' gender culture at general secondary schools. The problem of forming high school students' gender culture on the basis of understanding gender and gender equality is caused by the urgent need to overcome gender stereotypes and discrimination of men and women in the present-day Ukrainian society. At the theoretical level the authors substantiate the need to organise high school students' educational activity on the basis of fundamental principles of the gender-oriented approach whose implementation provides the creation of conditions necessary for the development of high school students individual potential, skills for constructive inter-gender interaction and influences the formation of high school students' gender culture effectively. Authors discuss various approaches to understanding the essence of the notion of "gender" and provide their own definition. Gender is defined as a complex formation which affects a person's understanding of his/her role and behaviour within the social and cultural norms and rules of a particular society which govern the constructive interaction between its members. The principles of forming high school students' culture are determined, namely, the principle of accessibility of all types and forms of educational services; the principle of considering gender differences and individual peculiarities of high school students; the principle of creating equal conditions for maximizing high school students' potential and identifying their needs; the principle of choosing individual educational trajectory.

Key words: high school students' gender culture; individual potential of development; constructive inter-gender interaction skills; general secondary schools; principles of forming high school students' gender culture. 